\title{
PROPAEDEUTIC, BASIS FOR CONSTITUTION, AND STATUTE OF THE BANK OF HUMAN EMBRYONIC AND FETAL CELLS
}

\section{Rudolf Klen}

University Teaching Hospital Hradec Králové: Regional Transplantation Centre

In memory of I. Hradil

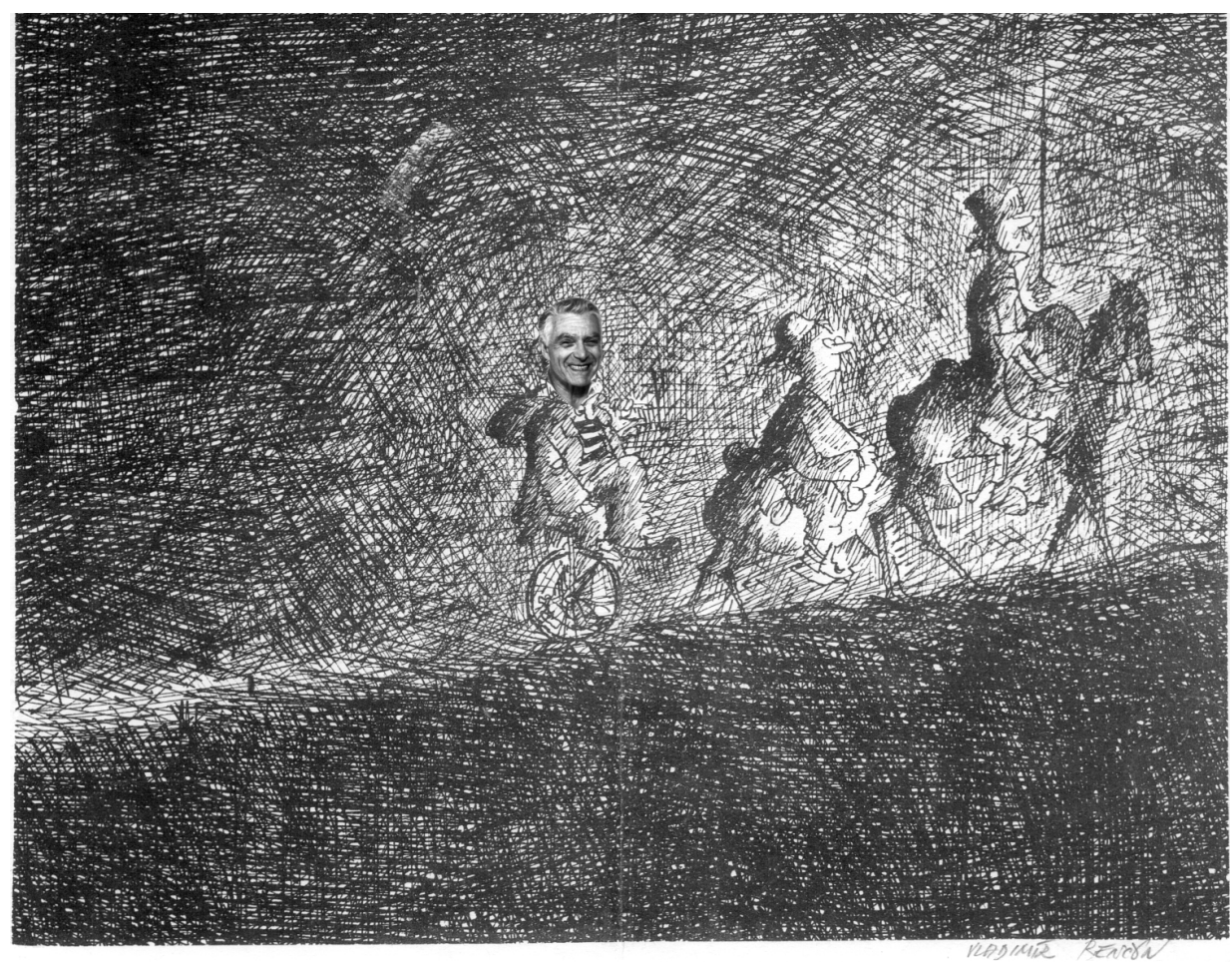

\section{Contents}

1. Preface

2. Introduction

3. Biological predispositions

4. Legal regulations in the Czech Republic

5. Recommendations of the European Council

6. Ethics

7. Definitions

8. Accreditation

9. Donorship of aborted embryo

10. Information for donors

11. Anamnestic data and donation declaration of the donor

12. Anamnestic data of the biological father

13. Introduction to the reflection on the effects of xenobiotics on human embryo and fetus
14. Macroscopic external morphology

15. Good laboratory practice

16. Request form: Application for human embryonic or fetal cells for research purposes

17. Request form: Application for human embryonic or fetal cells for clinical transplantation

18. Letter accompanying the delivery of embryonic or fetal cells intended for research

19. Letter accompanying the delivery of embryonic or fetal cells intended for clinical use

20. Statute of the bank of human embryonic and fetal cells

21. Epilogue

22. Annexes 


\section{Preface}

According to my original conception, the results of biological research can be classified in three categories. The first group comprises results of basic biological research, those which reveal entirely new fundamental information and penetrate deep into novel fields. Using figuratively the terminology of war journalists of the $2^{\text {nd }}$ World War, this is the "Panzerspitze" thrusting into the territory of the enemy, which is ignorance in our case as an opposite to knowledge. The second group is what I call "complementary" research: the results of basic research are extended in severa related neighbouring fields and the fundamental knowledge in a certain region is thus broadened in a mosaic pattern resulting in a comprehensive picture of systemic knowledge. The third group is the domain of applied research. Researchers here make use of data supplied by the former two categories, and apply them to the solution of practically oriented tasks whose solution can be directly utilized in everyday life.

When contemplating whether or not to apply for a grant which would make it possible to elaborate a concise report on all aspects of the "Statute and legal guidelines for the constitution and accreditation of the bank of human embryonic and fetal (brephoplastic) cells (BBC)" I realised that this topic does not properly fit into any of the mentioned three categories. A logical question must therefore be asked: What is it then? I came to the conclusion that an acceptable solution of the conclusion that an acceptable solution of the challenging subject would be facilitated by "auxiliary" research in the fields of clinical embryology, teratology and associated regions. New data here will open up a broad avenue which will make it easier to complete the needed knowledge and ensure that no legal, ethical or administrative obstacles, however tempting, will hinder the progress neither in research nor in clinical utilization. Apart from that, then will shorten the period of initial groping.

\section{Introduction}

In physics, which is one of the fundamental natural sciences, three fixed points guarantee stability. The same holds true for the solution of problems associated with rational-charitable use of aborted human embryos and fetuses (E/F in further text). There exist right biological predispositions whose implementation contradicts neither law nor ethics.

\section{Biological predispositions}

When compared to adult cells, the E/F cells offer the advantage of certain preferable properties with respect to transplantation $(3,7)$. First, they are immunologically undifferentiated, and it can be assumed that both the host's reaction to the implantation of $\mathrm{E} / \mathrm{F}$ cells and the re- action of grafted E/F cells against the host's antigens will be weaker (3). E/F cells also contain numerous growth factors $(4,7)$ which facilitate their proliferation and taking (3). Their capability to differentiate and adapt to foreign environment is high (2). Moreover, they are more resistant to ischemia (8) an attribute which is important during the withdrawal and processing. Since they usually do not adhere firmly to each other and their outgrown processes are rather short, they can be easily separated (6). At the same time, however, these properties, might theoretically augment the risk of malignant conversion of the implanted E/F graft. Research along this line has so far not substantiated the reality of such fears. The author is not aware of any published data documenting malignant transformation of transplanted $\mathrm{E} / \mathrm{F}$ cells. The specific properties of $\mathrm{E} / \mathrm{F}$ cells seemingly bear exciting potentialities which almost resemble Jules Verne's phantasy novels.

Together with a group of specialists in those fields where the E/F cells are likely go be useful, I have set up a list of diagnoses designated by codes suggested by the International Classification of Diseases (the $10^{\text {th }}$ revision). The list was subjected to a scrutiny by L. Strnad, member of the Center of Medical Information at the Faculty Hospital Hradec Králové. The analysis revealed some interesting conclusions. Out of the 41376 in-patients admitted to treatment at the Faculty Hospital in the year 1995, some 3960 to 5300 subjects were potential candidates for transplantation of E/F cells. An extrapolation to the whole population of the Czech Republic (10,5 million) increases the number of prospective recipients to $152000-206000$ out of the total of 1879000 hospitalised patients. Even if one assumes a rate of therapeutic success as low as $1 \%$, the resulting numbers must necessarily convince even the staunchest critics that the use of human E/F cells - provided all ethical requirements are fully met - clearly complies with the main ethical mission of medicine - i.e. to reduce the suffering of sick people (5). One of the overly optimistic visionary articles, the paper by Brustire (1), stresses the particular advantages of the use of $\mathrm{E} / \mathrm{F}$ stem cells in the treatment of certain serious disorders of the central nervous system. Embryonic stem cells seem to possess a number of additional invaluable potentialities for clinical use.

I have recently distributed my tentative draft on the constitution of BBC to those learned societies of the Czech Medical Association for which the therapy with $\mathrm{E} / \mathrm{F}$ cells is likely to be of interest, and requested an official standpoint. Positive replies returned from the following societies: Czech Anatomical Society, Czech Society for Diabetology, Czechoslovak Biological Society, Society for Neurosurgery, Society for Ophthalmology, Society for Orthopedy, Society for Esthetic Surgery and Society for Medical Genetics. Consensual support was also obtained from the Scientific Council of the Medical Faculty, Hradec Králové, the Scientific Council of the Military Medical Faculty, Hradec Králové, and Institute of Microbiology of the Czech Academy of Sciences. 


\section{References}

1. Brustle $\mathrm{O}$ et al. Embryonic cell derived glial precursors. Science 1999;285(5428):754-6.

2. Ducsay CA. Fetal and maternal adaptations to chronic hypoxia. Comp Biochem Physiol Mol Intergr Physiol 1998;119(3):675-81

3. Fine A. Human fetal tissue research. Cell-Transplant 1994;3(2):113-45.

4. Heinz-Erian $P$ et al. Maternal smoking and inhibition of fetal growth factor JAMA 1998;279(24):1954.

5. Klen R. Aborted embryos: law and ethics. Bull Med Eth 1998;February:22-5.

6. Parer JT. Effects of fetal asphyxia on brain cell structure and function. Comp Biochem Physiol Mol Integr Physiol 1998;119(3):711-6.

7. Rajhjen PD et al. Properties and uses of embryonic stem cells. Reprod Fertl Dev 1998; 10(1):31-47.

8. Richardson BS, Bocking AD. Metabolic and circulatory adaptations to chronic hypoxia in the fetus. Comp Biochem Physiol Mol Integr Physiol 1998;119(3):717-23.

\section{Legal regulations in the Czech Republic}

The act No. 66/1986 of the Czech National Council made an elective abortion possible. Decree No. 75//1986 regulates the implementation of the law. The Ministry of Health Care of the Czech Socialist Republic issued a decree on November 9, 1987 (No. 19/1988) which states in paragraph 18 that „the remains, in particular aborted or prematurely born human fetuse ${ }^{\mathrm{x}}$ ) as well as body parts and organs removed from dead or living subjects, and other remains - unless they are used for scientific, therapeutical, preventive or educational purposes - shall be buried in a cemetery area or incinerated in facilities of medical centers, provided there is no suspicion of a criminal offense".

It is the responsibility of the gynecologist who performs the abortion to decide whether or not a criminal offense is suspected. In case of a justified suspicion the remains are not transferred to BBC; instead, the police must be notified, and the police authorities will decide on further course of action. The decision on how to utilize properly the cells for scientific, therapeutic, preventive or educational purposes, it is for charitable-rational use, rests with he head of the BBC. Case history, medical examinations of both parents, and examination of the aborted $\mathrm{E} / \mathrm{F}$ are factors that are taken into consideration (see chapters 11-14).

Several relevant questions touching on ethical problems emerge immediately: Is the disposal of $\mathrm{E} / \mathrm{F}$ to burial or cremation really an ethical conduct if it can evidently help sick people? Is the respect to buried or incinerated $\mathrm{E} / \mathrm{F}$ rightfully greater than to $\mathrm{E} / \mathrm{F}$ used for charitable-rational purposes?

\section{Recommendation of the European Council}

In 1986 the Council of Europe issued its recommendation No. 1046 to all member states in which it suggests a ban on industrial use of E/F. In 1989, the Parliamentary Assembly of the Council of Europe formulated its position on the use of human E/F scientific research.

Recommendation No. 1100 states in section F: "On dead embryos and foetuses 15 . Before proceeding to any intervention on dead $\mathrm{E} / \mathrm{F}$, centres and clinics shall ascertain whether death is partial (when the embryo is clinically dead, its cells, tissues or organs may still remain alive for several hours) or total (when clinical death is matched by death of the cells) 16. The use of biological matter from dead $\mathrm{E} / \mathrm{F}$ for scientific, preventive, diagnostic, therapeutic, pharmaceutical, clinical or surgical purposes shall be permitted within the framework of the rules governing investigation, experimentation, diagnosis and therapy, in accordance with the terms of this recommendation".

\section{Ethics}

The author of this text considers any human $\mathrm{E} / \mathrm{F}$ to be a developing human being, yet unable to survive outside the organism of the mother. Once the symbiosis with the maternal organism is severed, the E/F dies after a certain period of time which has not yet been precisely ascertained. This time interval is generally longer than in adult age, because the $\mathrm{E} / \mathrm{F}$ cells are more resistant to lack of oxygen. As long as the $\mathrm{E} / \mathrm{F}$ is alive, it deserves the same degree of respect as any human being; after death, it deserves the some respect as a deceased person. By Czech jurisdiction, aborted $\mathrm{E} / \mathrm{F}$ has the nature of human „remains“, i.e. an object sui generis (9).

The author discussed in more details the ethical problems of BBC in several publications. A general information for medical community at large appeared in 1994 in weekly periodical Zdravotnické noviny under the title "Co může medicína? (What are the potentials of medicine?) (2). In collaboration with the philosopher J. Jebavý is reflected in a paper "Fetal tissue banks need ethical code" published in Bulletin of Medical Ethics (UK) (3). Biologically oriented readers were addressed in a paper entitled "Even the dead are helping" published in Vesmír (4) in Czech and translated into English for publication in Tissue and Cell Report (5), a journal of the American Association of Tissue Banks. The history of how the deceased can help the living is outlined there. An article "Aborted embryos - law and ethics" appeared in Praktický lékař (6) in Czech and was reprinted in English version in Bulletin of Medical Ethics (UK) (7). Since this text deals with the basic imperative of medicine - help to sick subjects, it has also been submitted for consideration before the Central Ethical Commission of the Ministry of Health Care. The commission concluded that "there are no principal objections to the ethical aspects of the paper". "A pilot study on the public opinion poll concerning the use of aborted human embryos" appeared in "Praktický lékař" (8). It provided basic guidelines for the planning of similar largescale projects. From the chairman of the ethical commission of the world-wide Transplantation Society I received the "Position paper on foetal interaction". This document contains six principal points related to human E/F. The proposed statute of BBC is in accordance with all. Detailed

x) correct medical terminology would be „embryos and fetuses“ 
consideration of international regulations governing the research involving human $\mathrm{E} / \mathrm{F}$ can be found in a paper by Andrews et al (1). The authors quote, among others, the noteworthy ruling of the Federal District Court in the U.S.A. that the banning of research activities using human $\mathrm{E} / \mathrm{F}$ is illegitimate, because it violates the basic right of women to their privacy. Since the placenta and umbilical cord are parts of the E/F, it would be appropriate to extend the legal and ethical norms so as to cover these organs as well.

\section{References}

1. Andrews $\mathrm{L}$ et al. International regulation of human embryo research. Human Reproduction 1998;13(1):1.

2. Klen R. Co může medicína? Zdrav noviny 1994;33:18.

3. Klen R, Jebavý J. Fetal tissue banks need ethical code. Bull Med Eth 1995; January:18-20.

4. Klen R. I mrtví pomáhají. Vesmír 1997;květen:255-6.

5. Klen R. Even the dead are helping. Tissue Cell Report 1997;411:3-4

6. Klen R. Potracená embrya - právo a etika. Prakt Lékař 1998;78(6):336-7.

7. Klen R. Aborted embryos - law and ethics. Bull Med Eth 1998;February:22-5.

8. Klen R. Pilotní studie průzkumu veřejného mínění na užití potracených embryí Prakt Lékař 1999;79(11):648-52.

9. Štěpán J. Právo a moderní lékařství. Praha: Panorama, 1989:487.

As the three basic prerequisites have been met, an actual establishment of $\mathrm{BBC}$ then requires the elaboration of administrative foundations, particularly the conditions of accreditation, principles of good laboratory practice and statute.

Financial funding is needed to make all these plans real. The author drew attention to this essential requirement as long ago as 1969 in his lecture on "Basic Considerations for the Establishment of Bone Marrow Bank" when he warned: "Every project in health service should primarily contain a purely medical nucleus which, however, is enveloped by a solid coat of economy that determines the level and extent of the care to be provided" (Bone Marrow Conservation, Culture and Transplantation, International Atomic Energy Agency, Vienna, p. 187).

\section{Definitions}

Exactly defined terminology is needed for perfect understanding and avoidance of possible misinterpretation. Definitions of terms used throughout this text are therefore included.

Abortion - spontaneous expulsion of $\mathrm{E} / \mathrm{F}$ from the womb before the end of the $28^{\text {th }}$ week of gestation; the weight of aborted $\mathrm{E} / \mathrm{F}$ is below $500 \mathrm{~g}$.

Abortion induced (elective) - intentional termination of pregnancy before the end of the $28^{\text {th }}$ week of gestation

Auxiliary compounds - chemicals that have no therapeutic effect by themselves and are used during preparation of the graft.

$B B C$ - a non-profit laboratory which collects, examines, processes, preserves and distributes cells and tissues obtained from legally or spontaneously aborted human $\mathrm{E} / \mathrm{F}$ or their parts. Preceding voluntary and informed consent of the donor is required. The processed material is made ava- ilable for activities in research, education and treatment after an explicit approval by the appropriate ethical commission. The $\mathrm{BBC}$ cooperates with the users in the evaluation of results.

Batch - a group of grafts prepared in the same work cycle. It can be assumed that individual biological properties of grafts of the same batch have been exposed to the same extrinsic factors.

Birth - expulsion of vital $\mathrm{F}$ exceeding $500 \mathrm{~g}$ in weight and $35 \mathrm{~cm}$ in length from the uterus of a pregnant women, applies also to $\mathrm{F}$ of parameters lower than $500 \mathrm{~g}$ and $35 \mathrm{~cm}$, as long as the fetus lives at least $24 \mathrm{~h}$ (heartbeat, breathing, movements of limbs and head). If born dead, F must weigh at least $1000 \mathrm{~g}$ to call it birth.

Brephoplastic cells (1) - E/F fetal cells.

Cooling, hypothermic preservation - maintaining the object at low temperature, yet above $0^{\circ} \mathrm{C}$.

Distribution - the way in which the graft is transferred from $\mathrm{BBC}$ to the user who requested it.

Embryo (human) - E, early stage of development of a human organism, a configuration of undifferentiated cells from the beginning of the $2^{\text {nd }}$ to the end of the $8^{\text {th }}$ week of gestation.

Embryology - the science dealing with development, structure and activities of $\mathrm{E} / \mathrm{F}$.

Expiry - time indication designating the limit beyond which the graft is no longer safely applicable.

Fetus (human) - F unborn human organism in later stages of development from the beginning of organogenesis in the $9^{\text {th }}$ week of gestation until birth.

Freezing cryothermic preservation - maintaining the object at temperatures below $0^{\circ} \mathrm{C}$ making water turn into ice.

Good laboratory practice - precise respecting of all imposed rules during withdrawal, processing. examination, preservation and distribution of the graft.

Graft - biological material duly examined and properly processed so as to be suitable for experimental or clinical transplantation.

Handling the graft - all processes to which the biological material is subjected in BBC. It include all activities performed by other laboratories upon special demand of BBC.

Identification code final - sequential number of the remains procured in the given year (e. g. 42/1998).

Identification code withdrawal - sequential number and date of the day when the tissue was withdrawn (e. g.6/12-61998).

Organogenesis - time interval between the $20^{\text {th }}$ and $60^{\text {th }}$ day of pregnancy characterised by differentiation of cells to form organs.

Preparation of the graft - handling of biological material in the course of graft processing.

Preparer - laboratory entrusted with the procurement of biological material, its examination and processing, preparation and distribution of grafts.

Preservation, (conservation) - methods which make it possible to extend the expiry time of the graft. 
Price of the E/F graft or E/F cells - the sum of expenses incurred during the procurement, examination, processing, preservation and distribution of the material.

Processing - adaptation of the biological material to suit he requirements of research or therapy.

Shelf time - the time period for which the preserved biological material is stored.

Supercooling - maintaining the object at temperatures below $0^{\circ} \mathrm{C}$ but with water remaining in liquid phase.

Teratology - the science of morphological and functional pathology of $\mathrm{E} / \mathrm{F}$.

Undesirable effect - adverse, unwanted reaction of the recipient to grafted transplant.

User - institution or subject requesting a biological material for its ethically approved use.

Viability of $E$ - manifestation of normal basic life signs, such as heartbeat, metabolism, movements of limbs and head.

Viability of E cells - manifestation of normal basic cellular processes, such as detectable proliferation.

Vitality - quantity of life manifestations.

Vitrification - a method of freezing preventing the formation of crystalline ice.

1. May RM. La greffe brephoplastic 1935;16 Nov:1851. Sometimes it is of advantage to use this greek word instead of usual latin synonymes as it is not provocative for some people.

\section{Accreditation}

The realization of conditions for $\mathrm{BBC}$ accreditation guarantees that he planned functions of the bank can be executed in accordance with the required standard. The conditions relate to four categories.

1. Organization

1.1. Definition of main tasks of the BBC and its position in the founding institution.

1.2. Collaboration with units entrusted with the procurement, examination and application of the material

1.3. Organisation of $\mathrm{BBC}$ :

1.3.1. Directorate (an embryologist, a clinically oriented specialist in handling $\mathrm{E} / \mathrm{F}$, and the head of $\mathrm{BBC}$ ).

1.3.2. Task groups:

1.3.2.1. Advisory

1.3.2.2. Evaluation of results

1.3.2.3. Control (particular aspects: ethics, economy, documentation)

1.3.2.4. Cooperation with users

1.3.3. Responsibility for execution of tasks:

1.3.3.1. The $\mathrm{BBC}$ head is responsible for activities sub 1.3.1., 1.3.2.1., 1.3.2.2., 1.3.2.4., for systematic growth of professional as well as general (safety measures, fire precaution) qualification of the staff, for compliance with laws and rules, record keeping, ethics, activities of higher professional staff (university graduates, heads of working groups, chief administrator).
1.3.3.2. Subordinate professionals are responsible for the functioning of individual task groups and for proper documentation, mainly with respect to the completeness of data. 1.3.3.3. Technicians are responsible for exact laboratory work.

2. Staff

2.1. Graduated professionals are expected to improve systematically their speciality and their general qualification; they are subjected to regular health tests; they are charged with record keeping.

2.2. Technical staff is expected to improve systematically their special and general qualification; they are subjected to regular health tests; they are responsible for the maintenance of laboratory hoods.

2.3. Administrative unit.

2.4. Glass cleaning. general cleaning personnel.

3. Work space of adequate size is required. The rooms must be arranged so as to be easily maintained, cleaned and ventilated with fresh air. The space must be dry, properly lighted, equipped with running cold and hot water; the temperature is kept reasonably constant.

3.1. Access to laboratory space for aseptic preparation and cell culturing is permitted only to authorised personnel.

3.2. Separate rooms for freezing and storing

3.3. Room for glass cleaning

3.4. Ready-to-use storing room (including cold-storage of liquids).

3.5. Studies for professional staff (confidential documents are kept in the office of the BBC's head).

3.6. Secretariat (usually combined with social activity room).

3.7. Cloakrooms, water closets, showers.

4. Equipment of laboratories

4.1. Laboratory equipment, apparatuses and tools must be adequately chosen and kept in good operational state. One member of the technical staff is charged with the duty to take care of laboratory equipment. Any defect is to be immediately reported to him and other staff members are informed at the next regular morning meeting. The kind of defect, date and details on repair are recorded in the book of maintenance and repairs.

4.2. Special records are kept on culture media and chemicals (see Chapter 15).

4.3. Written instruction shall be worked out for each laboratory technique and must be always at hand. Every violation shall be immediately reported to the superior and a remark made in the relevant protocol, together with an account of the reasons and the actual alternative technique used.

4.4. Record is kept of each specimen of material, describing its entire history from procurement till dispatch. Records are handled as confidential data.

4.5. Each preserve is properly labeled with final identification code. A register of cryogenic storage allows exact location of any stored graft.

4.6. Personnel working in laboratories must wear protective clothing. Eating, drinking and smoking is prohibited in laboratories. 


\section{Sources}

Accrediation standards and Guidlines for IVF Laboratories. 1996:32. Am Soc for Reproductive Medicine: Fert Steril 1998;70/4 (Suppl. 3):9. Am Soc for Reproductive Medicine: Fert Steril 1998;70/4 (Suppl. 3):10 Dawon K. Hum Repod 1997;12(12):2590.

Embryologists. Registered in England No 2883756.

Kodex práv pacientů. Centrálni etická komise Min zdravotnictví ČR 1992.3.

Membership Directory 1991-1993 Am Association of Tissue Banks, 16.

Metodický návod Min. zdravotnictví ČR 11 OZP/2-2. VIII. 97.

Směrnice ředitelstlví FN v Hradci Králové 3/97.

Soc for Assisted Reproductive Technologies: Fert Steril 1998;704 (Suppl. 3):7.

\section{Donorship of aborted embryo or fetus}

For any legal use of aborted E, no matter whether the abortion is spontaneous or induced, it is important to designate the person who is entitled to make valid decision on further fate of the aborted tissues. If $\mathrm{E} / \mathrm{F}$ were considered to be just body parts of the pregnant woman, the tissue would be sent to morphological examination, which is a procedure routinely used in case of any surgically removed body parts. Such microscopic examination would actually confirm the pregnancy and exclude the possibility of an unrecognised disease.

As has already been said, E/F represent stages of a developing human being who is not, however, in a position to decide on own further fate, either from the biological or legal viewpoints. Biological incapability is given by functional and intellectual immaturity preventing the formation of coherent ideas, not to speak about communication ability. Legal incompetence rests in the age, which is below the age specified by law for legal responsibility. It is therefore necessary to determine who can rightly make a decision on the E/F's further fate.

Let us first consider the woman and her motivation to pregnancy termination. There may be two medical indications. First, abortion recommended by physician who may have arrived at the conclusion that continuing pregnancy would seriously deteriorate the health state of the pregnant woman, and might possibly even put her life in jeopardy. Secondly, genetic indication is based on unfavourable prognosis of the development of $\mathrm{E} / \mathrm{F}$ due to adverse genetic factors substantiating a high probability of an inherited disease or anomaly (1). The most frequent motivation, however, is rather personal, some reasons which for the woman in question seem so grave that it leaves her no other way out than induced termination of the life of a developing human being. The relevance and weight of such individual reasons are very difficult to judge. Medical indications as well as some special individual personal motives (e. g. rape, particularly under alcohol intoxication, planned parenthood) cannot be a priori rejected. The validity of other reasons greatly depends on ethical approach, and this is deeply affected by religion, cultural tradition and social conditions of the mother's life. Is it in any way possible to compare the donation of $\mathrm{E} / \mathrm{F}$ for charitable-rational use with the situation where a living donor provides one of his kidneys to a person in need? What seems to be totally unacceptable is that a woman would become pregnant intentionally with a pre-planned idea to donate the aborted E for charitablerational utilization.

What is the role of the biological father in the decision process? He may appear in one of three possible positions: a legitimate husband, a stable partner or a casual partner. In any of the three cases the biological father either may have been informed of the pregnancy, or may be ignorant. If he knows and agrees with the abortion, he is logically a participant in the ethical aspect. If he is unaware of the pregnancy or is against the abortion, he may be cleared from the "complicity". The question is whether he has any right to express his opinion about donation, if he disapproves of the abortion. The contrary seems obvious: if he agrees, he should have his word in the decision on donation. But again: if his opinion is sought but no reply is obtained, should the presumption of tacit consent be applied ("qui tacet assentire videtur")?

Under the assumption that the pregnant woman is willing to donate the aborted $\mathrm{E}$, all possible combinations of attitudes of the biological father are listed in the following table. The last column then shows what it will actually mean for the BBC. The results can be interpreted as follows: Line one: the combination is such that the resulting outcome is positive for the $\mathrm{BBC}$ that acquires the tissue. Line two: The result would be negative if the law sets down the father's consent as a necessary prerequisite. Line three: positive if the presumption of tacit consent is applied. Line four: positive because of the father's agreement with donation, despite his adverse attitude towards abortion. Line five: the result depends on whether the positive decision of the mother outweighs the refusal of the father. Line six: the outcome for the bank would be positive, if the attitude of the mother is recognised as decisive. Line seven: positive as no objection exists. Line eight: equivalent to five. Line nine: equivalent to three. Line ten: positive as no objection exists.

\begin{tabular}{|c|c|c|c|}
\hline Line & $\begin{array}{r}\text { Attitude of } \\
\text { abortion }\end{array}$ & $\begin{array}{l}\text { ogical father } \\
\text { donation }\end{array}$ & $\begin{array}{c}\text { Result } \\
\text { for BBC }\end{array}$ \\
\hline 1 & + & + & positive \\
\hline 2 & + & - & $?$ \\
\hline 3 & + & $\mathrm{n}$ & t.c. - positive \\
\hline 4 & - & + & positive \\
\hline 5 & - & - & $?$ \\
\hline 6 & - & $\mathrm{n}$ & $?$ \\
\hline 7 & $\mathrm{n}$ & + & positive \\
\hline 8 & $\mathrm{n}$ & - & $?$ \\
\hline 9 & $\mathrm{n}$ & $\mathrm{n}$ & t.c. - positive \\
\hline 10 & ignorant & ignorant & positive \\
\hline
\end{tabular}

$$
\begin{aligned}
& +=\text { agreement } \\
& -=\text { disagreement } \\
& ?=\text { questionable } \\
& \text { n = no reply } \\
& \text { t.c. = tacit consent ("qui tacet assentire videtur”) }
\end{aligned}
$$

Three particular questions still require a definite answer: 
1. Is the consent of the pregnant woman alone sufficient and is it possible to disregard the attitude of the biological father?

2. Can no reply be considered equivalent to tacit consent?

3. Does a consent of the biological father to donation mean his implicit agreement with abortion?

The author was able to trace only two publications dealing with the discussed problems. Vikhanski (3) describes a trial in which the attitudes of the two partners were contradictory and the court's verdict confirmed the exclusive rights of the pregnant woman. Similarly, Gazvani (2) considers the attitude of the biological father irrelevant.

\section{References}

1. De Grespigny. Mother and babis, pregnant women and fetus Br J Obstet Gynecol 1999;106(12):1235.

2. Gazvani MR. Gamets donors for IVF should relinquish right of ownership to resulting embryos. Br Med J 1998;316(7147):1829.

3. Vikhanski L. Who owns an embryo? Nat Med 1996;2(11):1164.

The scope and form of BBC's activities will to some extent be affected by the inclination of public opinion. As there is no doubt that it would be helpful to the BBC's authorities to have from the very beginning some knowledge of the prevailing trends, we have carried out an orientative small-scale public opinion poll to provide answers to several basic questions.

One hundred respondents who voluntarily took part in the project were given an information sheet (the same which will be routinely distributed to all candidates of elective abortion and which contains complete information needed for a qualified, informed consent to $\mathrm{E} / \mathrm{F}$ donation see Chap. 10) together with a questionnaire reproduced below. The questionnaire intended for male participants differed only in the formulation of question no. 2.

Groups of respondents

1. subjects without university education

1.1. males (10)

1.2. females (10)

2. university students

2.1. medical students

2.1.1. males (10)

2.1.2. females (10)

2.2. students of Pedagogic Institute

2.2.1. males (10)

2.2.2. females (10)

3. university graduates

3.1. medical doctors ${ }^{\mathrm{x}}$

3.1.1. males (10)

3.1.2. females (10)

3.2. graduates of Pedagogic Institute with diploma

3.2.1. males (10)

3.2.2. females (10)
Questionnaire

Bank of human brephoplastic cells, Faculty Hospital, Hradec Králové

Dear respondent,

public opinion about the use of aborted human embryos and fetuses for legitimate charitable-rational purposes (education in medicine and biolo$g y$, research on human development, treatments of severe diseases such as Parkinson's disease) is likely to influence the activities of the BBC. You are therefore asked to kindly fill in the following anonymous questionnaire.

1. Check the group to which you belong:

without university education

medical student

student of other university school

physician

graduate of other university school

2. In case a woman becomes pregnant and decides to undergo induced abortion (curettage, miniinterruption), she can in accordance with the law also decide on further fate of the aborted E/F. Check the way which you yourself would select in such hypothetical situation:

incineration or burial

charitable-rational use (education in medicine and biology, research on human development, therapy, e. g. of Parkinson's disease).

Check further what is your opinion about the following questions related to donation of $E / F$ :

3. Is the decision of the pregnant woman alone sufficient? yes - no

4. Is it necessary to take the attitude of the biological father into consideration? yes-no

5. If both parents are not of the some opinion, who's opinion is decisive? his - hers

6. In your opinion, can no reply be taken as a tacit consent? yes - no

Alternative question no. 2 for male respondents:

The following table lists all three theoretically possible attitudes of the pregnant woman. Please check in the right half of the table the way which you yourself would choose in such hypothetical situation

\begin{tabular}{|c|c|}
\hline Attitude of the pregnant woman & $\begin{array}{l}\text { Position of the biological father } \\
\text { to donation of } E / F\end{array}$ \\
\hline $\begin{array}{l}\text { Consent to both abortion } \\
\text { and donation }\end{array}$ & $\begin{array}{l}\text { agree } \\
\text { disagree } \\
\text { undecided }\end{array}$ \\
\hline $\begin{array}{l}\text { Consent to abortion, } \\
\text { refusal of donation }\end{array}$ & $\begin{array}{l}\text { agree } \\
\text { disagree } \\
\text { undecided }\end{array}$ \\
\hline $\begin{array}{l}\text { Consent to abortion, } \\
\text { undecided about donation }\end{array}$ & $\begin{array}{l}\text { agree } \\
\text { disagree } \\
\text { undecided }\end{array}$ \\
\hline
\end{tabular}

When evaluating the answers, the ratios 10:0, 9:1 and 8:2 of positive to negative replies are taken as statistically significant at the $5 \%$ level using the one-sided alternative of the sign test.

The pilot study of the public opinion allowed to draw the following usable information:

The majority of women of all 5 groups would donate aborted E/F for charitable-rational use. Only 3 out of 50 respondents (i.e. $6 \%$ ) preferred burial or incineration.

If the pregnant woman agrees with charitable-rational use of the aborted $E / F$, the majority of male partners of all groups tested would concur. Only 6 out of 50 male respondents (i. e. $12 \%$ ) would decide otherwise.

${ }^{\mathrm{x})}$ one half are practising physicians, the other half are engaged in teaching or research 
All respondents (i. e. $100 \%$ ) agree that the attitude of the pregnant woman is decisive.

Three groups of female respondents are convinced that the attitude of the biological father need not be taken into account. Only 5 out of 50 (i.e. 10 \%) female respondents think otherwise.

No reply to the question on donation of $E / F$ is taken as tacit consent only by the group of medical doctors, whereas 2 groups significantly disagree. There was no significant difference between the attitudes of students of two university schools - medicine and pedagogics.

Respondents of medical profession differ from those of pedagogic profession only in their attitude to question no. 6, which however, is of minor importance.

The conclusions seem encouraging for the perspectives of BBC's activity, and justify a larger-scale project that would adequately complete the tentative data.

Thanks are expressed to B. Kraus, PhD. and J. Mokrý, M. D., PhD. for help in data collecting, and L. Strnad, PhD. for consultation on statistics.

\section{Information for donors}

An information sheet has been prepared containing ful and credible information in order to facilitate the decision of the pregnant woman and the biological father on donation of E/F. If any suspicion exists that the psychical condition of the pregnant woman is altered to an extent that it would put the credibility of her decision in doubt, consultation of a qualified psychiatrist is recommended by the person distributing the information.

Bank of Human Brephoplastic Cells, Faculty Hospital, Hradec
Králové
To whom it may concern,

No doubt you know that blood donated by one person can be used to restore health of a number of other subjects, sometimes even save their lives. Similarly, burned patients are successfully treated with transplants of skin taken from donors. Modern medicine can cure even otherwise fatal diseases of liver, kidney, heart, lungs and pancreas by transplantation of donated organs.

You have decided to have your pregnancy terminated. A decree of the Ministry of Health Care (no. 19/1988, paragraph 18) states that the tissues obtained at abortion are to be either buried or incinerated, or alternatively may also be used for charitable-rational purposes, such as education of health professionals, research on human development, and treatment. The Council of Europe in its Recommendation no. 1100/1988 names the same areas of charitable-rational use.

The bank of human embryonic and fetal cells is a non-profit institution which collects cells obtained at abortions and - observing fully the respect deserved by a developing human being-processes them so as to be available for such charitable-rational purposes that have been approved by relevant ethical commissions. It is strictly forbidden to use the tissue for any other purpose. Your consent with a gratuitous use of the E/F tissue for charitable-rational purposes can be regarded as an expression of unselfish human solidarity and good sense for general welfare of human society, or as a gracious gift possibly restoring the health of another sick human fellow. Nobody will be reimbursed for your priceless gift.
In order to ensure the best possible utilization of the tissue, it is essential that you answer truthfully a few questions related to health care matters. The questions are essentially the same as those posed to any blood donor. The information will then be completed with the results of immunological examinations using a sample of your blood taken immediately before abortion. The test on AIDS infection caused by $\mathrm{HI} v \mathrm{i}$ rus must be repeated after an interval of 3-4 months. The results are very valuable for you, as the examinations can reveal possible latent infection without any manifest symptoms.

All these data are subject to medical secrecy, any disclosure is qualified as a criminal offense. The entire documentation is kept as confidential. However, it is obligatory to report certain specified contagious diseases to the authorities of Public Hygiene.

Should you feel that you need a more detailed explanation before you are albe to make up your mind, do not hesitate to contact the person who distributes this information. It is also this person to whom you can convey your final decision on the donation of tissues obtained during your operation.

\section{Anamnestic data and donation document of the donor}

If the pregnant woman decides to donate the $\mathrm{E} / \mathrm{F}$, she has to fill in a questionnaire characterizing her health state, and sign a donation document.

Bank of human brephoplastic cells, Faculty Hospital, Hradec Králové Confidential

Withdrawal identification code

Final identification code

After I read the information sheet which I fully understood, I decided voluntarily to donate gratuitously the tissues obtained at my elective abortion to be used for charitable-rational purposes (education in medicine and biology, research on human development, treatment $e$. $g$. of Parkinson's disease). I agree that the actual utilization of the tissue will be determined by specialists who will take into account my truthful replies to relevant medical questions, the results of laboratory tests, as well as examination of a sample of my blood taken immediately before abortion. I have been informed that the test on HIV must be performed twice and am willing to undergo repeated examination.

Surname and first name

Personal identification number

I am ........... years old, this is my ........ pregnancy

Any previous spontaneous abortion (date, diagnosis) ........

Any previous stillbirth (date, diagnosis) ..........

I have been occupationally exposed to ionizing or electromagnetic radiation, infectious material, poisons or other noxious agents. Check which risk you have been exposed to.

Occupation

I have never had a tumour, do not loose weight, do not sweat profusely, have no swelling of lymph nodes, do not cough, do not have fever or diarrhea. Indicate only yes or no 
I am presently undergoing medical treatment for .........

I am presently under medication with (specify the name of the medicaments, dose, frequency, duration of medication) ..........

In recent time I have been using the following medicines (specify the name, dose, frequency, when terminated) ........

The occurrence in my family of Creutzfeld-Jacob's disease, any hereditary disease, any congenital malformation: yes - no - do not know.

If you have ever suffered from some of the following diseases: mononucleosis, brucellosis, malaria, tularemia, toxoplasmosis, listeriosis, borreliosis, German measles, gonorrhea, tuberculosis, syphilis, infectious jaundice type B or C, AIDS, do not say which, only check yes or no.

I use drugs, am registered as drug abuser, am prostitute, have frequent intercourses with different partners particularly when abroad; I have been immunized, treated with growth hormone, blood transfusion, transplantation. I have been imprisoned. In recent six months I have not been attacked by an animal or found an attached blood-sucking tick, had no close contact with persons suffering from jaundice or AIDS. Again check only yes or no.

I agree that a sample of my blood will be taken immediately before abortion to examine it for signs of possible contagious diseases. This includes a test on the presence of HIV which causes AIDS. This test must be repeated in 3 to 4 month time, i.e. ..........

I agree that neither me nor anyone else will be told how the tissue has finally been used. I waive any rights to reimbursement for the gift.

I am aware of the possibility to revoke my decision within 7 days. If the revocation comes later, $i$. e. after ........... or if I do not comply with the requirement of a repeated HIV test, I would have to defray the expenses of immunological examinations.

To decide to which purpose the aborted $E / F$ is right it is necessary to know also the anamnesis of the biological father. If you agree, the information that you have just read, and special questionnaire for biological father will be passed over to him, please write his name.

I know that all data are subject to medical secrecy and their unauthorized disclosure is a criminal offense; I also know that the documents will be handled as confidential matter.

I confirm that all I wrote is true and nothing was concealed. I am aware of the fact that false and incomplete information could potentially jeopardize those who handle the tissue or are treated with it. Such misinformation is unlawful.

I have signed this statement voluntarily, because I regard donation of $E / F$ as beneficial and ethical.

Date

Signature of donor

Signature of witness

\section{Anamnestic data of the biological father}

Provided that the pregnant woman indicate the name of biological father information for donor and questionnaire dealing with the anamnesis is passed over to him.

Even if the consent of the biological father with donation will not to be necessarily required by law, some anamnestic and medical data of the male partner would still be needed for the tissue to be applicable for any clinical treatment and for some research use.
Bank of human brephoplastic cells, Faculty Hospital, Hradec Králové Confidential

Withdrawal identification code

Final identification code

................. who became pregnant after intercourse with me made up her mind to donate gratuitously the remains of the aborted E/F for charitable-rational purposes (research, education, therapy). Since the utilization of the tissue may be affected by information related to my health state, I am truthfully answering the questions in this questionnaire. I also agree with laboratory examinations of my blood including the test on HIV causing AIDS. I am aware of the fact that the HIV test must be performed twice and am willing to undergo a repeated blood sampling. I am informed that neither me nor anyone else will be told anything about the actual utilization of the tissue.

I am ........ years old

Personal identification number ..............

Occupation .........

Some men have sexual intercourse with numerous female partners. Try to remember whether any woman pregnant with you experienced a spontaneous abortion. Yes - no - do not know.

I have been occupationally exposed to ionizing or electromagnetic radiation, infectious material, poisons or other noxious agents. Check which risk factor you have been exposed to.

\section{I am employed .............}

I have never suffered from a tumour disease, I do not loose weight, do not sweat profusely, have no swelling of lymph nodes, do not cough, do not have fever or diarrhea. Indicate only yes or no.

I am at present undergoing medical treatment for .......

Present medication (name of the medicament, dosage, duration, last dose).

Occurrence in the family of hereditary diseases, congenital malformations, Creutzfeld-Jacob's disease. Yes - no - do not know.

If you have suffered from the following disease: mononucleosis, brucellosis, malaria, tularemia, toxoplasmosis, listeriosis, borreliosis, German measles, gonorrhea, tuberculosis, syphilis, infectious jaundice type B or $C$, AIDS, do not say which, only check yes or no.

I use drugs, am registered as drug abuser, have frequent intercourses with different partners particularly when abroad. I have been immunized, treated with growth hormone, blood transfusion, transplantation. I have been imprisoned. In recent six months I have not been attacked by an animal or found an attached bloodsucking tick, had no close contact with person suffering from jaundice or AIDS. Again check only yes or no.

I agree that a sample of my blood will be taken to examine it for signs of possible contagious diseases. This includes also a test on the presence of HIV which causes AIDS. This test must be repeated in 3 to 4 month time, i. e. .......

I agree that neither me nor anyone else will be told how the tissue has finally been used.

I am aware of the possibility to revoke my decision. If the revocation comes later than 7 days after the abortion, $i$. e. ......... or if I do not comply with the requirement of a repeated HIV test, I would have to defray the expenses of immunological examinations.

I know that all data are subject to medical secrecy and their unauthorized disclosure is a criminal offense; I also know that the documents will be handled as confidential matter.

I confirm that all I wrote is true and nothing was concealed. I am aware of the fact that false and incomplete information could potentially jeo- 
pardize those who handle the tissue or are treated with it. Such misinformation is unlawful.

I have signed this statement voluntarily, because I regard donation of $E / F$ as beneficial and ethical.

Date

Signature of donor

Signature of witness

The gynecologist who performs the abortion receives from the representative of the $\mathrm{BBC}$ a written confirmation of the transfer of biological tissue.

Bank of human brephoplastic cells, Faculty Hospital, Hradec Králové Transfer of human embryonic tissue Withdrawal identification code

On ........... I accepted a specimen of human E/F tissue obtained at abortion of ............. on behalf of the $B B C$.

Signature

The following laboratory examinations of blood of the pregnant woman and the biological father will be determined:

Anti HIV 1+2, HIV 1Ag, anti HTLV I+II, HBsAg, anti $\mathrm{HBc}$ IgM, anti $\mathrm{HBc}$, anti HVC, anti CMV IgM, anti CMV IgG, anti VCA EBV IgM, anti HAV IgM, anti VZV IgM, anti VZV IgG, anti HSV IgM, anti Toxoplasmosis IgM, anti Toxoplasmosis IgG, BWR RRR, BWR TPHA.

All request forms and containers with biological materials sent to laboratory examinations are always marked with the final identification code. Blood samples obtained from the male partner and the pertaining request forms carry the final idification code with letter $\mathrm{M}$ appended.

The quarantine imposed on processed grafts intended for clinical use ends, if the results of laboratory examinations including the second HIV test are negative. In case of any positivity the staff members of the BBC who handled the graft must be examined to exclude possible acquired infection.

\section{Introduction to the reflection on the effect of xenobiotics on human embryo and fetus}

The main task of a BBC is to supply human brephoplastic cells for ethically approved research or treatment. Criteria for therapeutic application are logically more rigorous, and signs of infection, some pathological alterations and unfavourable anamnestic parental data indicating hereditary diseases will make the material unsuitable for clinical use. The following paragraph is conceived as an introduction to the deliberation on embryotoxic effects of xenobiotics. Such effects must necessarily be taken into account and will complement the data needed for a responsible decision on optimal use of the tissue.

From this viewpoint, xenobiotics can be grouped in three categories: medicaments, habitual drugs not used for therapeutic purposes, and abiotic components of human environment. Chemical factors affect both females and males, though the effect in males is probably less severe, because the sperm maturation cycle is shorter than that of the egg (10). Yet this does not mean that data provided by biological fathers on medication are superfluous, particularly as concerns treatment with cytostatics, hormones and immunosuppressive drugs.

\section{Medicines}

Medicines will be divided into four groups:

1. Preparations with no known deleterious effect on $\mathrm{E} / \mathrm{F}$ despite their even prolonged use by women before and during the pregnancy.

2. Preparations with suspected embryotoxicity even if used only for a short period of time. When evaluating their effects, it is essential to bear in mind that it may sometimes take even months after the termination of medication before the consequences can be safely excluded (6).

3. Preparations that are clearly embryotoxic and are therefore contraindicated during pregnancy. This category comprises also medicaments which damage oocytes in non-pregnant women, such as psychotropic drugs causing mutations or chromosomal aberrations (10). Data derived from animal expriments are valuable, but cannot be directly transposed to humans. This is evidenced by a surprising finding of Shepard (20) that out of about 1200 known animal teratogens only about 30 have been confirmed as teratogenic in humans. A well-known example of embryotoxic compounds is methotrexate, which was reported to cause spontaneous abortion in $95 \%$ of pregnant women (15). The teratogenic effect of thalidomide (Contergan) (13) caused a world-wide shock. Data on E/F teratology attributable to the use of medicaments began to accumulate only as late as in the $70 \mathrm{~s}$, and this can explain the limits of our knowledge. Moor's schema (16) (Appendix 1) depicts very illustratively the adverse consequences of the use of medicamental teratogens for $\mathrm{E} / \mathrm{F}$. The effect depends on many factors, such as dose, length o-exposure, way of administration, and inherent properties of the preparation (i. e. $\mathrm{pH}$, solubility in fats, degree of ionization, molecular weight). The effect develops gradually and involves the pregnant woman, subsequently the placenta and finally the embryo, as well. One of the possible reactions to the penetrating substance is biotransformatin; consequently, the teratogenic effect is induced by a compound different from that which was originally administered. Biotransformation takes place sooner and is more marked in human than in animal embryos (10). Noxious agents can sometimes accumulate in various organs. For instance, the immature hemato-encephalic barrier in embryos permits greater accumulation of some substances in the central nervous system. The ultimate effect depends on different factors (e. g. genetic, interference with other compounds) and is difficult to predict. In 
fact, even a surplus of vitamin A is detrimental (1). Somewhat surprising but noteworthy is Koren's (12) finding that a combination of contraceptive agents must be considered teratogenic.

As radiation is also a therapeutic agent, it will be dealt with here. Nakagawa et al. (17) are convinced that a therapeutic dose of ionizing radiation administered between the $2 \mathrm{n}^{\mathrm{d}}$ and $8^{\text {th }}$ week of gestation is likely to cause malformation of the E. In the subsequent period, from the $8^{\text {th }}$ to the $25^{\text {th }}$ week, it may result in mental retardation. Later on the danger rapidly decreases. The risk has a clear-cut threshold dose estimated at $0.1 \mathrm{~Gy}$.

Data on the effect of medication upon sperm are much scarcer. Potentially spermiotoxic are for instance preparations containing sulfasalzin, antihypertonics, antibiotics, cytostatics, anabolic hormones and glycolic ethers. Their effects on spermatozoids can extend over several years (18).

\section{Habitual drugs not used as pharmaceutical preparations.}

It is certainly remarkable that the following word appeared in the Bible more than 2000 years ago in the Book of Judges (13; 41): "You shall be with child and shall give birth to a son. Beware, do not drink wine or other intoxicating beverages". A confirmation of the validity of this eternal truth can be found in many modern scientific studies on the deleterious effect of ethanol upon embryogenesis. Blum (2) attributes it to the reaction of the reduces the mitotic rate in all cells with high metabolism. The result is hypertrophy and hyperplasia. Brichová (4) described serious damage to kidneys, liver and intestine, retarded differentiation of diencephalon and reduced cellularity of cerebellar cortex in rat fetuses exposed to ethanol. An editorial of JAMA (9) concludes that detrimental intrauterine development continues even postnatally and results in a defective functioning of CNS. Church et al. (7) published data on experimental and clinical observations documenting adverse consequences of alcoholic syndrome in F affecting hearing, speach and vestibular functions in newborns. The effect of ethanol is especially strong in twins (10). Smoking is another frequent embryotoxic agent (24). Cotton (8) found smoking more damaging to the developing $\mathrm{F}$ than cocaine. By weighing 712 newborns of smoking mothers it was established, that the average weight was significantly lower if smoking was combined with alcohol consumption. No relationship was found between coffee drinking and neonatal weight (21). A study comparing the frequencies of eye malformations (subconjunctival and retinal hematomas, malfunction of optical nerve) in newborns of mothers addicted to cocaine and those with no drug abuse (40 in each group) found no differences (22). Another opthalmological study documents the undesirable effects of alcohol on growth and formation of the developing eye in humans (22). Parajaninen and co-workers (19) collected evidence on toxic damage to spermatozoids of large doses of ethanol. Nieschlag's (18) comprehensive monography quotes no data on the influence of smoking and drug abuse.

\section{Abiotic components of external environment}

Unlike the substances discussed in the preceding two chapters, abiotic components of human environment (such as increased concentrations of sulfur dioxide, pesticides, exhaust gases) influence not only individual subjects, but expose large populations and often affect even succeeding generations (5). Boulton (3) compares the effect of dioxines and polychlorated biphenyls to that of the lack of thyroid hormone causing mental retardation and defective intelligence. Abiotic environmental factors affect populations of ever increasing size. Injuries of pelvis and testes, elevated average temperature, radiation (ionizing as well as microwaves), occupational exposure to lead, fluor, cadmium, pesticides and herbicides, these are all factors listed by Steeno (23) as damaging for spermatozoids. A good example of a systematic study analyzing the effects of noxious occupational factors in crude oil industry is a paper published by McMartin et al (14). They compiled and evaluated all data which appeared in scientific journals in the time period from 1966 to 1996

\section{Conclusion}

The decision whether or not it is safe to use aborted $\mathrm{E} / \mathrm{F}$ cells of parents who have been influenced by known medication is an uneasy task even for experienced pharmacologists. A useful guidance in the practice is the classification of the State Institute for Drug Control assigning medicaments to the three mentioned groups. However, the classification may change as new data become available which will determine with greater precision how long it takes before the $\mathrm{E} / \mathrm{F}$ cells return to normal state after the exposure to contraindicated medicines or other noxious agents has been stopped.

\section{References}

1. Bernhardt IB, Dorsey DC. Hypervitaminosis A and congenital renal anomalies in a human infant. Obstet Gynecol 1974;43(5):750-75.

2. Blum A, Loser H. Diagnose der Alkoholembryopathie. Dtsch Med Wochenschr 1995;120(6):184-9.

3. Boulton A. Common pollutans may harm fetus. Br Med J 1996;312(7045):1498.

4. Brichová H. Fetální alkoholový syndrom (Fetal alcohol syndrom) 37. meeting of the Czech Anatomic Soc. Brno, 1996.

5. Buyse ML. Birth defects encyclopedia. 1996 Vol II. Ctr for Birth Defect Information Sources, Dover 1990:684.

6. Cameron JS, Ogg CS. Sterility and cyclophosphamide. Lancet 1972;1(7761):1174

7. Church MW, Kaltenbach JA. Hearing, speech, language, and vestibular discorders in the fetal alkohol syndrom. Alcohol Clin Exp Res 1997;21(3):495-512.

8. Cotton P. Smoking cigarettes may do developing fetus more harm than ingesting cocaine, some experts say. JAMA 1994;271(8):576-7.

9. Editorial: From the centres for disease control and prevention. JAMA 1995;273(18): 1406.

10. Elis J., Elisová K.: Léky v těhotenství. Avicenum Praha 1983; 346

11. Hellstrom A et al. Eye size in healthy Swedish children and children with fetal alcohol syndrome. Acta Ophtalmol Scand 1997;75(4):423-8.

12. Koren G. Drugs in pregnancy. N Engl J Med 1998;338:1128.

13. McBridge. Autism in thalimidon embryopathy. Teratology 1997;16:79.

14. McMartin KJ, Koren G. Proactive approch for the evaluation of fetal safety in chemical industries. Teratology 1996;130:412. 
15. Mitchell AA, van Benekom CM. A pregnancy prevention program in women of childbearing age receiving isotretinoin. N Engl J Med 1995;333(2):101-6.

16. Moor KL. The developing human. Sanders Co London 1982 (according to Elis).

17. Nakagawa K et al. Radiotherapy during pregnancy. Clin Ther 1997;19(4):770-7.

18. Nieschlag E. Andrology. Berlin: Springer, 1997:624.

19. Pajarinen J. Alcohol and fetus demage. Int J Androl 1994;17:292.

20. Shepard TH. Catalog of the teratogenic agents $6^{\text {th }}$ ed. Baltimore: J. Hopkins Univ. Press, 1989:287.

21. Shu XO et al. Maternal smoking, alcohol drinking, caffeine consumption, and fetal growth. Epidemiology 1995;6(2):115-20.

22. Stafford JR et al. Prenatala cocaine exposure and the development of the human eye. Ophtalmology 1994;101(2):300.

23. Steeno OP. Occupational influence on male fertility and sterility. Andrology 1984;16(1):5.

24. Van de Kamp JL, Collins AC. Perinatal nicotine alters nicotinic receptor development in the mouse brain. Pharmacol Biochem Behav 1994;47(4):889-900.

\section{Commentary}

It is evident from what has been explained above that embryotoxicity of therapeutic agents is of great importance for the existence of $\mathrm{BBC}$. One of the future research projects where the participation of $\mathrm{BBC}$ is highly desirable, is likely to be a more precise definition of embryotoxicity of medicines that are already in the market. Systematic examination of aborted $\mathrm{E} / \mathrm{F}$ of women who have been treated with drugs before becoming gravid or in the course of their pregnancy offers a unique opportunity to effectively attack this problem. The vast extent of the task becomes obvious if one realizes that approximately $80 \%$ of therapeutic agents listed in Medistránky 1998 are either contraindicated or non recommended during pregnancy. Even if one admits that these characteristics are perhaps stricter than necessary just to be on the safer side, it still opens an immense, attractive research field for the support of pharmaceutical industry. Almost totally neglected up to now is the area of the effect of paternal medication on the conceived $\mathrm{E} / \mathrm{F}$. There is no doubt that BBC would welcome any meaningful collaboration with pharmaceutical companies, because it may bring the much sought financial funds. On the other hand, better knowledge of drug embryotoxicity would reduce the degree of unnecessary caution about the possible risk of damage to $\mathrm{E} / \mathrm{F}$ due to the intake of medicines, and would ultimately increase the production and profit of pharmaceutical industry.

On December 11, 1998, an advertisement appeared in the journal Science on page 1994 soliciting E/F tissues for non-profit research. The Birth Defect Research Laboratory at the University of Washington, which placed the ad in the journal, distributes a concise, general information on activities of the laboratory to all who have been addressed by the ad and suggests direct contacts with potential customers. Other articles, such as Thomson's paper "Funding of human embryo research in the US" published in Nature Biotechnology 1999; 17: 312, or Wadman's publication in Nature 1999; 400/6742: 301 imply that projects using human $\mathrm{E}$ could be carried out legally if financed from private sources, while the same projects would probably be refused as unethical if funds were requested from the NIH granting agency. Mastroiani (Andrology 1999; 20/6: 688) claims that such opinions find a clear reflection in changes of the
USA opinion characterized by gradual softening of restrictions in the utilization of human E. It is therefore not surprising that one can read quite new papers advocating commercial exploitation of stem cells (e. g. Birmingham, Nature Medicine 2000; 6/3: 237) and the paper Vogel C.: Congress investigate fetal tissue sales published in Science 2000; 287/5460:1903.

\section{Macroscopic external morphology}

The results of clinical transplantation of human E cells greatly differ. Both astounding successes and total failures have been reported. Ahmad (1) described successful transplantation of mesencephalic cells derived from human $\mathrm{E}$ in a patient with Parkinson's disease. The treatment restored normal level of dopamin for a period of 10 years. One can only regret that the biological parameters of the graft are only poorly defined (number of cells, their age, functional competence). The lack of such details is a common drawback of most publications on this subject: the characterization of the graft is never complete. This makes it very difficult to say with confidence that grafts with really suitable parameters were used for the expected results. In order to ensure that only grafts with reasonably good chances of success are used in clinical treatment, it will be necessary to strictly control the basic parametrs.

The cell count can be relatively easily determined by techniques routinely used in hematology. Since the viability and functional capacity depend on age, the age of the embryo will have to be assessed. Anamnestic data on the duration of pregnancy as provided by the donor (best estimation is the number of days elapsed from the first day of the last menstruation) will be recorded in the protocol on "Macroscopic external morphology of the embryo". The protocol will also contain data on the size of $\mathrm{E} / \mathrm{F}$ and on morphological features. Moor's scheme (Annex 1) describes individual stages in the development of human $\mathrm{E} / \mathrm{F}$ and their susceptibility to teratogens (2).

Annex 2 shows schematically the way how the size of $\mathrm{E}$ is determined (7). Annex 3 presents the relationship between the age and the measured distance top of the head coccyx (5); annex 4 gives the same for the distance top of the head - heel (5).

The most frequent size parameter quoted in publications is the "height in sitting position", i. e. the distance top of the head - coccyx. Since all data on size measurements must be regarded as only approximate, it is necessary to complete them with details on the developmental stage by describing the characteristic elements of the face and the limbs.

Annex 5 illustrate schematically the development of the entire human E approximately between the $24^{\text {th }}$ and $30^{\text {th }}$ day. Annex 6 illustrate the development between the $33^{\text {rd }}$ and $42^{\text {nd }}$ day of gestation (5). The scheme in Annex 7 shows the developmental formation of the face (5). Annex 8 presents the developmental scheme of the external ear 


\section{(5). Annex 9 that of the limbs (5).}

The member of the BBC's staff who is charged with the processing of the material records all data on macroscopic external morphology in the Protocol. When evaluating the significance of the recorded findings it is necessary to bear in mind that the morphogenesis of the $\mathrm{E}$ may be influenced by both internal factors (such as chromosomal, functioning of the placenta, capability of $\mathrm{E}$ to utilize nutrients) and factors of external environment to which the pregnant woman is exposed.

Elective abortions are performed from the $4^{\text {th }}$ to the $11^{\text {th }}$ week of gestation; the majority (some $80 \%$ ) in the $6^{\text {th }}$ or $7^{\text {th }}$ week.

As a rough guidance, the following features of external morphology can be regarded as indicative of the age of the E (according to Klika -5 and O'Rahilli - 7):

Week 4: the head part and rudiments of upper extremities are visible, eyelids and mouth depression are discernible.

Week 5: neck, rudiments of lower extremities and elbows are formed. Face elements are distinctly differentiated: eyelids, nose, rudimental auricle, mouth.

Week 6: auricle and fingers are formed, discernible knee joint.

Week 7 and 8: head, neck, all limbs, elbows and knees can be clearly distinguished. Facial features are further developing.

Since all data on morphology are subject to a considerable variance, exact determination of the age of $E$ is not possible. However, an increasing frequency of observations will make the assessment more precise Rtg examination (8), ultrasound (6) and magnetic resonance (4) are techniques enabling the determination of morphological details of $\mathrm{E}$ and consequently its age. It can be confidently predicted that these methods will be further refined and will furnish more reliable data on earlier developmental stages. It should also be mentioned that histological examination of skin sections from $\mathrm{F}$ beyond 14 weeks of age can provide good estimates of the age (3).

\section{References}

1. Ahmad K. Embryonal grafts have long-term benefit in Parkinson disease. Lancet 1999;354(9193):1882.

2. Elis J, Elisová K. Léky v těhotenství. Praha: Avicenum, 1982:347.

3. Erch J. Assesing gestational age from histology of fetal skin. Obstet Gynecol 1999;5(94):753.

4. Garel $\mathrm{C}$ et al. Magnetic resonance imaging of the fetus. Pediatr Radio 1998;28(4):201-11

5. Klika D. Embryologie. Praha: Avicenum, 1987:384.

6. Kurmanavicius $\mathbf{J}$ at al. Fetal ultrasound biometry. Br $\mathbf{J}$ Obstet Gynecol 1999:106(2):136-43.

7. O'Rahilly R, Müller F. Human embryology and teratology. Wiley-Lies, 1992:512.

8. Warren MV. Radiographic determination of developmental age in a fetus and stil born. J Forensic Sci 1999;44(4):78

Protocol of external macroscopic morphology and processing of an embryo - fetus

Bank of human brephoplastic cells, Faculty Hospital, Hradec Králové Confidential
Withdrawal identification code

Final identification code

Duration of pregnancy: indication of the donor by morphological parameters of $E / F$

Spontaneous abortion: complete, incomplete ${ }^{x}$

Induced abortion: curettage, mini-interruption ${ }^{x}$; for medical reasons on the part of the mother, for genetic reasons

Operation: time of beginning $(h, \mathrm{~min})$

Procurement of material ( $h$, min)

Embryo: whole, intact - damaged $\left.{ }^{x}\right)$

Part of embryo ${ }^{x}$ : head: damaged - intact; left arm: damaged - intact; left leg: damaged - intact; right leg: damaged - intact; trunk: damaged - intact

Proportions: top of the head-heel. $\quad \mathrm{mm}$, ultrasound $\mathrm{mm}$ top of the head-coccyx $\quad \mathrm{mm}$, ultrasound $\mathrm{mm}$ lower extremity $\quad \mathrm{mm}$, ultrasound $\mathrm{mm}$

Eyelids, nose, mouth, auricle, neck, fingers, toes ${ }^{x x}$

Other finding including anomalies

Beginning of processing ( $h, \mathrm{~min})$

Processing (medium)

Microbiological examination

Preservation (medium; hypothermic, \% of cryoprotective agent, medium, cryopreservation, vitrification, graphic recording)

End of processing $(h, \mathrm{~min})$

x) Cross out what is inappropriate or missing

${ }^{x x}$ Undiscernible feature - cross out; slightly suggested - leave unmarked; clearly visible - underline.

Date

Signature

\section{Good laboratory practice}

Records will be kept indicating the following information details about all culture media: type, manufacturer, batch number, exspiry date, date of delivery and dates of use, storing temperature.

If possible, water used in processing technologies should be of the same quality as that required by pharmaceutical industry for preparation of hypodermic injections. If not available, bidistilled, apyrogenic, sterile water is to be employed. Vessels with water are clearly marked with the name of the manufacturer and date of preparation, and are stored in refrigerators.

What has been said about culture media pertains also to human albumin. Blood serum, used as a supplement to culture media should preferably be obtained from the potential recipient of the graft.

Aseptic conditions will always be maintained, even if the tissue specimen is designated for morphological research.

From the time of tissue sampling till cryopreservation the material is to be kept at lowered temperature. Never must the temperature exceed $37^{\circ} \mathrm{C}$.

When handling the tissues, it is advisable to make use of sterile laminar flow hood. The potential advantage of fumebouble technology during mini-interruption might be worth testing.

The use of disposable tools and utensils is preferable if the graft is intended for clinical treatment. 
All types of containers holding processed biological material are to be visibly marked with final identification code.

Freezing devices and protective equipments for manipulation with liquid nitrogen must be operational and ready to use. The level of liquid nitrogen in storing containers, as well as the temperature there must be checked daily. Measuring devices are controlled at yearly intervals.

One member of the BBC's staff shall be charged with the task of regular supervision of flawless working conditions of instruments and tools. He is to be notified immediately if any defects appears, and the entire staff will be informed at the next regular morning meeting. Details on repair (date, work performed, name of the serviceman) will be recorded in the book of maintenance and repair.

In order to prevent contamination of the stored biological material with liquefied nitrogen, the samples intended for clinical use shall be kept above the nitrogen level. If the specimen is to be submerged in nitrogen, it must be placed in a tightly sealed container. The tightness will be checked before freezing. If the material is known to be contaminated or if any suspicion arises, it is advisable to store it separately.

Records on stored matter must allow reliable localization of each sample. The accuracy of the recording shall be checked annually.

During the entire time period of storage in the BBC, every tissue sample shall be handled with due piety and respect, such as parts of human body deserve. One member of the BBC's staff will be responsible for discarding (by incineration or burying) the remaining $\mathrm{E} / \mathrm{F}$ matter not used for the purposes of the BBC.

\section{Sources}

1. Dawson K. J.: Quality control and quality assurence in IVF laboratories in the UK, 8. Hum. Reprod. 1997; 12/12: 2590-2591

2. Klen R.: Řád perfusní služby Tkáňové ústředny Hradec Králové 1981, 6 .

3. Pool T. B.: Practicies contributing to quality performance in the embryo laboratory $1997 ; 12 / 12: 2591-2593$

\section{Request form: Application for human embryonic or fetal cells for research purposes}

Bank of human brephoplastic cells, Faculty Hospital, Hradec Králové Phone Fax E-mail

Date

I request a sample of human embryonic or fetal cells to be used in research project no........... Entitled

The project has been approved by the pertinent Ethical Commission. I promise to comply with all conditions specified by the BBC statute. Stamp of the applicant

Signature of the subject authorized to deal with $B B C$

\section{Request form: Application for human embryo- nic or fetal cells for clinical transplantation}

Bank of human brephoplastic cells, Faculty Hospital, Hradec Králové

Phone Fax E-mail

Date
I request a sample of human embryonic or fetal cells to be transplanted to .....

I promise to comply with all conditions specified by the BBC statute.

Stamp of the applicant

Signature of the subject authorized to deal with $B B C$

\section{Letter accompanying the delivery of embryo- nic or fetal cells intended for research}

Bank of human brephoplastic cells, Faculty Hospital, Hradec Králové

Phone Fax E-mail

Date

Name and address of the applying institution

Pursuant to your request dated .............. we are sending you a preserve of human brephoplastic cells batch no.

According to agreed conditions, the cells can be used exclusively at your institution and for the officially approved research. The cells must be handled with due piety. Any violation of these conditions may be subject to sanctions. If not used, return the preserve to the $B B C$.

Signature

\section{Letter accompanying the delivery of embryo- nic or fetal cells intended for clinical use.}

Bank of human brephoplastic cells, Faculty Hospital, Hradec Králové

Phone Fax E-mail

Date

Name and address of the applying institution

Pursuant to your request dated ............ we are sending you a preserve of human brephoplastic cells (final identification cod).

The specimen was prepared in compliance with your demands. The preserve is suitable for clinical use provided the container is undamaged upon delivery, properly labeled, and the temperature during transport was maintained between -150 and $-196{ }^{\circ} \mathrm{C}$. Even then the occurrence of infection cannot be entirely excluded. In case of any complaints please let us know immediately.

Prior to use, the preserve is to be immersed for $15 \mathrm{~min}$. in a water bath at $37^{\circ} \mathrm{C}$

The graft and the remaining unused parts of it must be handled with due piety.

The BBC would welcome prompt information on any possible damage to the container, faulty labeling, and excess temperature during transport. Should any clinical complications arise on the part of the treated patient, the $B B C$ must be notified without delay.

In order to evaluate jointly the prospects of transplantataion therapy with $E / F$ cells, BBC request a comprehensive report on the outcome of the treatment when the hospitalization is terminated and at follow-up after a time interval of one year.

Signature

\section{Statute of the bank of human embryonic and fetal cells}

The promising biological prospects of charitable-rational use (in research, education and treatment) of human $\mathrm{E} / \mathrm{F}$ cells, together with the legislature of the Czech Republic, recommendation of the European Union and respect to basic ethical principles have already created favou- 
rable conditions for the establishment of the bank of human E/F (brephoplastic) cells (BBC) in Czech Republic. Since the procurement and processing of such cells differ from the handling of mature human cells, tissues and organs for transplantation purposes, there seems to be a great need to set up a specialized institution to which those tasks could be entrusted.

\section{Introduction}

1. BBC is a non-profit laboratory engaged in the following activities:

1.1.1. Procurement, processing, preservation and distribution of human brephoplastic cells for ethically approved research.

1.1.2. Procurement, processing, preservation and distribution of human brephoplastic cells for ethically approved clinical utilization.

1.1.3. Evaluation of the results and future prospects jointly with the users.

1.2. The activities of BBC must be in accordance with the legislature of the Czech Republic and with accepted ethical principles.

1.3. BBC provides human brephoplastic cells preferentially to institutions and organizations in the Czech Republic. If there is no local need, the cells can be offered abroad on the condition that the legislature of the recipient state is compatible with legislature of the Czech Republic and the projects are ethically sound.

\section{Organization}

2.1. BBC is supervised by a directorate consisting of an embryologist, a representative of the supplied clinical institutions and the head of BBC.

2.2. It is the duty of each member of the directorate to employ his expert and human qualities to a steady improvement of performance standards of the BBC.

2.3. Members of the directorate approve the Statute and work rules of the BBC and guarantee their implementation. 2.4. In collaboration with nominated representatives of the supplied institutions, members of the directorate evaluate each year the functioning of the BBC and suggest operational changes as required.

2.5. Meeting of the directorate takes place every 6 months and any time in between, if the situation warrants. Meetings are convened by the head of the BBC. He prepares the programme and is responsible for official minutes. Records of the meetings are signed by all members and kept in archives. Suggestions for changes are submitted to the Ethical Commission for consideration.

2.6. All new members of the BBC's staff must be acquainted in detail with the statute and operational rules, and must sign a binding statement of compliance. Practicularly that they will not disclose to anybody confidential informations contained in the BBC's documents.

2.7. Any unavoidable deviation from the regulations of the Statute and work rules must be immediately reported to the BBC's head and subsequently recorded in writing in the
Protocol with full description and justification of alternative technologies used.

2.8. Each supplied institution designates one liaison person to conduct all negotiations with the BBC.

2.9. In order to survey the technical, legal, ethical and economical aspects of the activities of BBC, a control commission consisting of a physician-specialist, a lawyer, an ethician and an economist is nominated by the director of the hospital for a three-year term. The director designates the chairman of the commission whose vote is decisive. The commission meets once a year and anytime in between as the need may occur. Record is kept of the meeting containing all findings and suggestions for improvements. The chairman transmits the records to the director of the hospital; realization of suggestions is up to the director's discretion. Copies of the records are kept in the BBC's archives.

\section{Donorship}

3.1. The donor is an adult legally responsible pregnant woman who decides voluntarily - after having been fully informed about the relevant laws in effect and about the philosophy of donorship - to donate E/F tissues obtained at her induced abortion. She must receive complete information as early as possible prior to the operation. If the potential donor is below the age of consent or is certified, the entrusted guardian can legitimately decide on donation in her stead.

3.2. The director of the hospital and the head of the gynecologic unit where elective abortions are being performed sign an agreement.

3.2.1. The agreement specifies the dates and frequencies of induced abortions. The terms must be set with due respect to the health interest of the women to be operated.

3.2.2. The potential donor must be allowed sufficient time to weigh all arguments and decide freely on donation of the tissue for charitable-rational use. She will then be requested to fill in a questionnaire with anamnestic data, and sign a declaration of donation.

3.2.3. A member of the BBC's staff provide a sterile plastic bag and the operating gynecologist deposits the tissue inside. The closed bag is then placed in a second sterile container labeled with the withdrawal identification code. The code is also noted in the operational protocol.

3.3. The member of the BBC's staff expresses air from the bag, seals it and affixes the withdrawal identification code label to it. The code consists of the sequence number and date of induced abortion (e. g. 6/12 Dec. 98). The same code is entered in the operational protocol and the declaration of donation. The clinical unit receives a written confirmation of tissue transfer. After the tissue has been processed, the final identification code will be entered in each document.

3.4. If the biological father is known and willing, he will be requested to provide his basic anamnestic data in a special questionnaire.

\section{Transport of the tissues to BBC}

4.1. The tissues are transported in thermoboxes capable to maintain the temperature in a range of +1 to $+8{ }^{\circ} \mathrm{C}$. 
4.2. The quantity of tissues must not exceed the cooling capacity of the thermobox for the entire length of transport. 5. Processing of the remains and preparation of grafts.

5.1. Processing must begin as soon as feasible. The document on external macroscopic morphology shall also contain data on the temperature in the transfer box upon arrival, and on the length of hypothermic storage.

5.2. All preparations are carried out under aseptic conditions in hoods equipped with laminar flow of filtered air.

5.3. The same solution is used for transport of the tissue and preparation of the graft.

5.4. Cells intended for cryopreservation will be impregnated with cryoprotective substance.

5.5. Cells intended for clinical transplantation will be submitted to microbiological examination.

5.6. Processed tissues are transferred to special preservation beg and labeled with final identification code. This code consists of the sequence number of the current year (e. g. 6/99) and is subsequently entered in all relevant documents (anamnestic data and declaration of donation of the donor, anamnestic data of the biological father, protocol on external macroscopic morphology) next to the withdrawal identification code.

5.7. Next step is the programmed freezing or vitrification, followed by deposition in a cryobox above the liquid nitrogen level at a temperature ranging between -150 and $-180{ }^{\circ} \mathrm{C}$. The temperature is checked daily.

5.8. All unused and discarded parts of the tissue are incinerated.

5.9. The protocol on external macroscopic morphology is produced by the member of $\mathrm{BBC}$. The document is verified by the BBC's head and deposited in archives.

\section{Documentation}

6.1. Precaution is taken to maintain the confidential character of particular information for a time period of at least 10 years. This concerns the following documents:

6.1.1. Anamnestic data of the pregnant woman and declaration of donation.

6.1.2. Anamnestic data of the biological father.

6.1.3. Protocol of external macroscopic morphology.

6.1.4. Results of laboratory tests of the donor.

6.1.5. Results of examination of the remains.

6.1.6. Results of laboratory tests of the biological father.

Only the documents listed under 6.1.1. and 6.1.2. contain names as well as both identification codes. Item 6.1.3. contain both identification codes, whereas 6.1.4., 6.1.5. and 6.1.6. are identifiable only under the final code.

6.1.7. Waiting list of patients who are candidates for transplantation of $\mathrm{E} / \mathrm{F}$ grafts. The selection of recipients is made by the BBC's head.

6.1.8. Minutes of the control commission meetings.

6.2. Other documents display only the final identification code:

6.2.1. Inventory of stored cells.

6.2.2. Inventory of stored grafts.

6.2.3. Request forms applying for cells to be used in rese- arch. Contain also date of delivery, destination and final identification codes.

6.2.4. Request forms applying for cells to be used in clinical transplantation. Contain also date of delivery, destination and final identification codes. The person who signs the accompanying letter is responsible for proper selection; he eliminates the name of the recipient from the waiting list and notes the number of the request form in the inventory of stored cells.

6.2.5. Records of maintenance and repairs.

6.2.6. Records of used culture media, water and sera, recordings of the temperature in storing boxes, location of stored grafts.

6.2.7. Copies of outgoing mail.

6.2.8. Incoming mail.

6.2.9. These records and documents will be kept in archives for at least 5 years.

\section{Cooperation with supplied institutions:}

7.1. Cooperation in organizational matters see items 2.4 . and 2.8.

7.2. Operational cooperation: Each supplied institution nominates a representative with authority to deal with BBC. His duties include:

7.2.1. Registration of all request forms applying for material from the BBC.

7.2.2. Immediate reporting of any defects of received material.

7.2.3. Reports forwarded to BBC on the outcome of clinical treatment.

7.2.4. Participation in joint evaluation of results achieved.

7.2.5. Supply of material to institutions in foreign countries is subject to the same rules as those applicable to grafts to be used in clinical treatment.

\section{Epiloque}

\section{If only "iamque opus exegi quod nec Iovis ira nec ignis"}

Ovidius

Like anything else, a structure built on a green meadow is not an unmixed blessing: it has its advantages and disadvantages. If the aim is to lower the risks of unfavourable aspects - which of course is always desirable - the building site, the green meadow, must be all over thoroughly inspected. Potential threats and hazards have to be reduced, or the structure must be adapted so as to minimize the risk. This is the proper approach of a prudent architect. If this is not done, the building is put in jeopardy and, if the worst comes to the worst, may even collapse.

With the present paper I tried - to the best of my capability - to lower the dangers of potential pitfalls inevitably associated with the establishment of a BBC. I am well aware of the fact that I may not have been entirely successful, and I expect that some conceptions and suggestions which I myself consider essential will not be generally accepted 
and approved. Yet I daresay the criticism will come mainly from those who have not so far built any new structure on a green meadow, but were merely involved in modification or adaptation. Such tasks, though in no case entirely free from specific problems, have the great advantage of previous experience as a guidance.

I would be glad if disapprovals were not too numerous and if the basic principles were acceptable. I should hate to become Renčín's clown to whom I implanted my own head (see p. 123) and who takes part in the crusade of Don Quixote and Sancho Panza against windmills. I regret that my effort has not as yet met with much understanding of official authorities. I am therefore grateful to the Medical Faculty at Hradec Králové, a school whose graduate num- ber two I happen to be, for its kind willingness to let my ideas appear in printed form.

Thanks are due to the translator of the text $V$. Zelený M. D.

Submitted January 2000.

Accepted June 2000.

Prof. MUDr. Rudolf Klen, DrSc., University Teaching Hospital, Regional Transplantation Centre, 50005 Hradec Králové, Czech Republic.

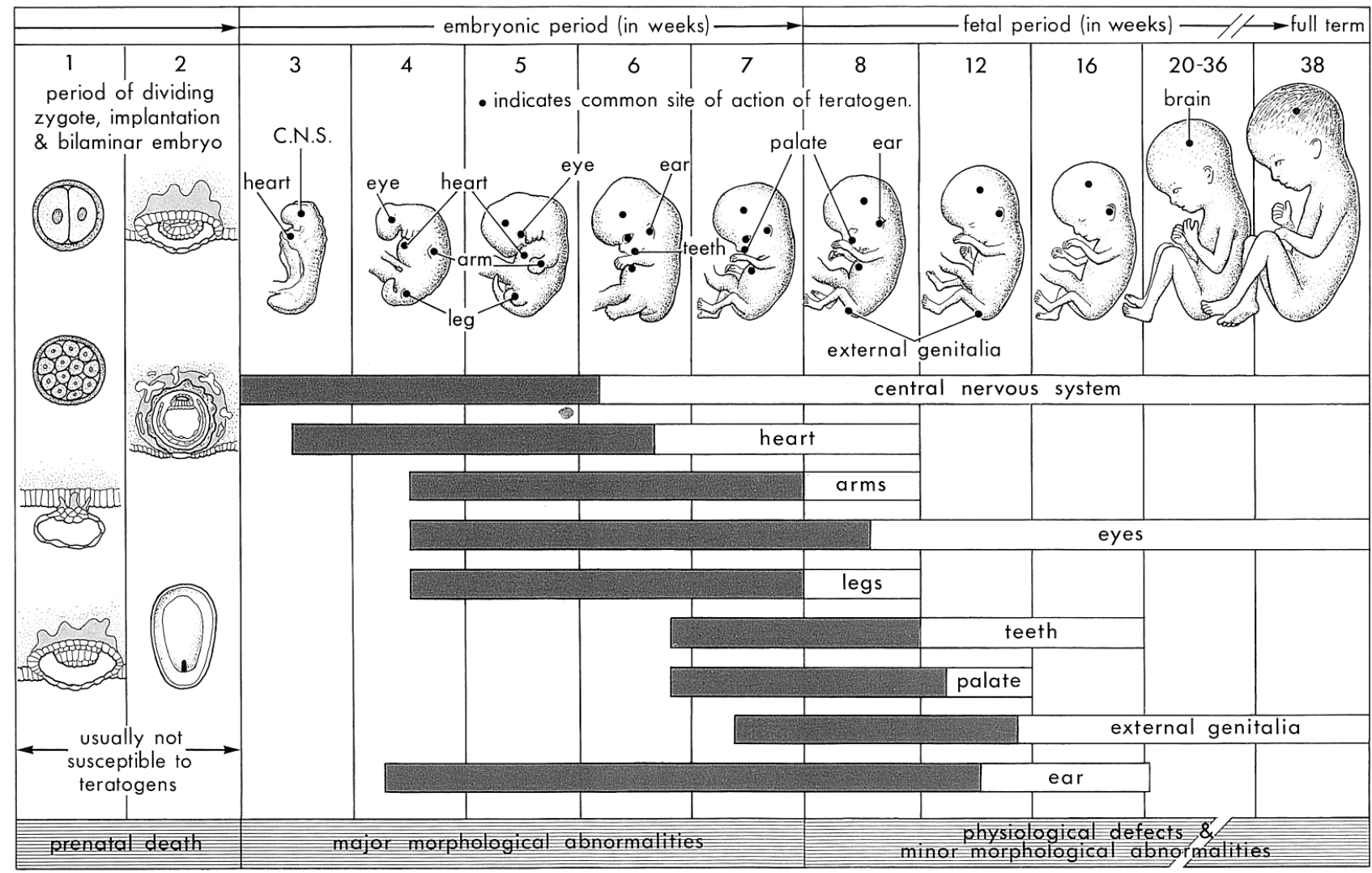

Annex 1: Schematic illustration of the sensitive or critical periods in human development. Black denotes highly sensitive periods: gray indicates stages that are less sensitive to teratogens. (K.L. Moore: The developing human clinically oriented embryology, Philadelphia - London - Toronto: W.B. Saunders, 1993, p. 117.) 
Annex 2: Right lateral views of embryo at 8 weeks $^{23}$, a newborn infant, and an adult, with the stature (C-H length) held constant. The adult head is proportionately half that of the newborn, which in turn is much smaller than that of the embryo. A horizontal line bisecting the newborn passes close to the umbilicus but is at the level of the pubic symphysis in the adult. The vertebral column (shown in black) is concave forward in the embryo, shows thoracic (T) and sacral $(\mathrm{S})$ curvatures in the newborn (the remaining two curvatures have begun but are less marked), and has four curvatures in the adult: cervical $(\mathrm{C})$, thoracic $(\mathrm{T})$, lumbar (L), and sacral (S). (C-H, crown to heel length: GL. greatest length of embryo, exclusive of lower limbs.) (O'Rahilly R, Müller F. Human embryology and teratology. WileyLies, 1992:512. - 7).

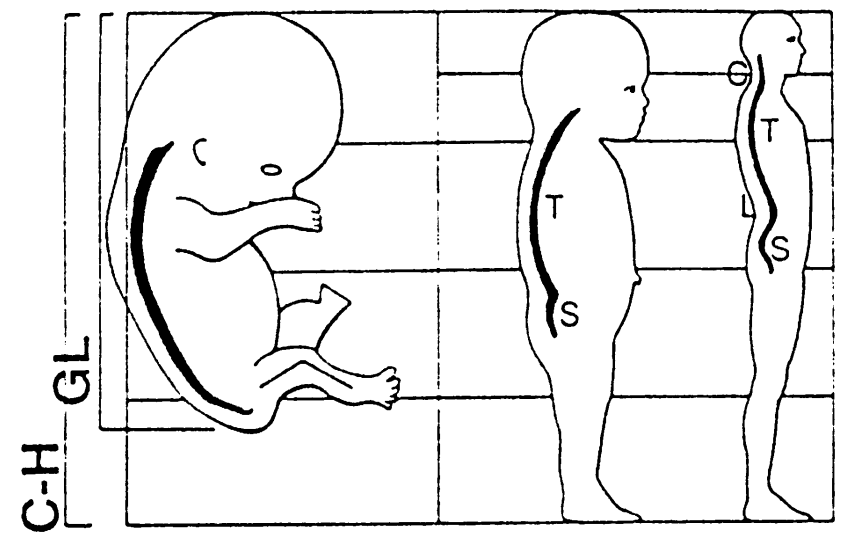

Annex 3: Relationship between the age of the E and measured length top of the head-coccyx (Klika D. Embryologie. Praha: Avicenum, 1987:384. - 5).

\begin{tabular}{|c|c|c|}
\hline \multirow{2}{*}{ Mm } & \multicolumn{2}{|c|}{ Days } \\
\cline { 2 - 3 } & Witchi & Streector-Daries \\
\hline 1.5 & 20 & $20 \pm 1$ \\
\hline 2.0 & 21 & \\
\hline 2.8 & 24 & $24 \pm 1$ \\
\hline 3.3 & 27 & \\
\hline 3.5 & 28 & \\
\hline 4.0 & 30 & \\
\hline 4.3 & 31 & $29 \pm 1$ \\
\hline 5.4 & 35 & $31 \pm 1$ \\
\hline 6.0 & $35-37$ & $35 \pm 1$ \\
\hline 8.0 & 38 & 37 \\
\hline 12.0 & $42-44$ & 39 \\
\hline 14.6 & $46-48$ & $45 \pm 1$ \\
\hline 17.0 & 50 & \\
\hline 25.0 & 56 & \\
\hline 45.0 & 70 & \\
\hline
\end{tabular}

Annex 4: Relationship between E length top of the head-coccyx or top of the head-heel and the age (Klika D. Embryologie. Praha: Avicenum, 1987:384. - 5).

\begin{tabular}{|c|c|c|c|c|}
\hline \multirow{2}{*}{ Week } & \multicolumn{2}{|c|}{ Top of head-coccyx } & \multicolumn{2}{c|}{ Top or head-heel } \\
\cline { 2 - 5 } & Streter & Patten & Arey & Haase \\
\hline 8 & 23 & $28-30$ & 30 & 40 \\
\hline 9 & & $39-41$ & & \\
\hline 10 & & $51-53$ & & \\
\hline 11 & & $64-66$ & & \\
\hline 12 & 74 & $77-79$ & 73 & 90 \\
\hline 13 & & $91-93$ & & \\
\hline 14 & & $105-107$ & & \\
\hline 15 & & $119-121$ & & \\
\hline 16 & 116 & $132-134$ & 157 & 160 \\
\hline 17 & & 147 & & \\
\hline 18 & & 160 & & \\
\hline 19 & & 173 & & \\
\hline 20 & 164 & 185 & 239 & 251 \\
\hline 22 & & 208 & & \\
\hline 24 & 208 & 230 & 296 & 300 \\
\hline 28 & 247 & 270 & 355 & 350 \\
\hline 32 & 283 & 310 & 409 & 400 \\
\hline 36 & 321 & 346 & 458 & 450 \\
\hline 38 & & 362 & 500 & 500 \\
\hline 40 & 362 & & & \\
\hline
\end{tabular}

Annex 5: External characterisation of morphological changes between $24^{\text {th }}-30^{\text {th }}$ day of development.
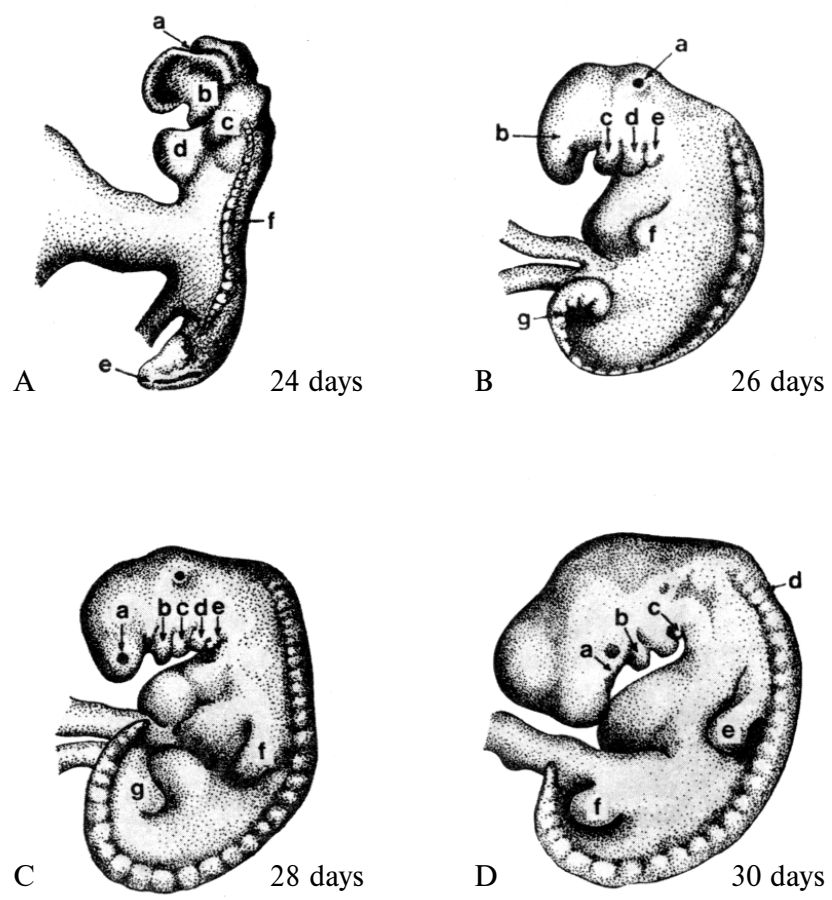

A-E 24 days old: a-neuroporus anterior, b-first pharyngeal arch, c-second pharyngeal arch, d-heart prominence, eneuroporus posterior. 
B-E 26 days old: a-otic pit, b-prosencephalon, c-first pharyngeal arch, d-second pharyngeal arch, e-third pharyngeal arch, f-proximal limb bud, g-tail.

C-E 28 days old: a-lens placode, b, c, d, e-4 developed pharyngeal arches, f-proximal limb bud.

D-E 30 days old: a-maxillar processes, b-mandibular processus, c-cervical sinus, d-pontine flexure, e-autopodium with finger rays separetd by depressions, f-distal bud. (Klika D. Embryologie. Praha: Avicenum, 1987:384. - 5).

Annex 6: Changes of external morphologic characteristics between 32 th-42th day of development.

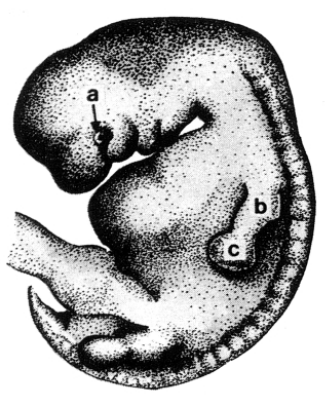

A

33 days

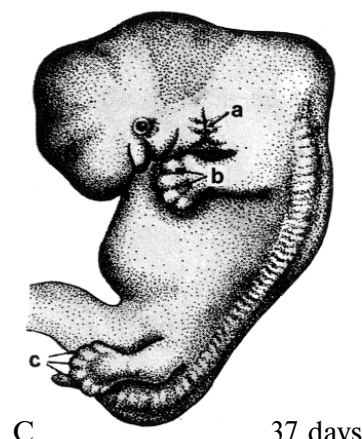

37 days

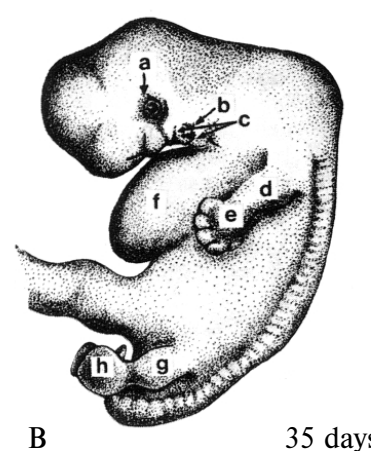

35 days

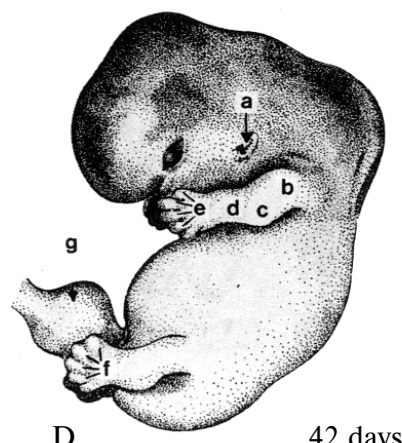

42 days
A-E 33 days old: a-primordium of the eye, b-zeugopodium, c-autopodium of the upper limb.

B-E 35 days old: a-primordium of the eye, b-external acustic meatus, c-developing pinna, d-zeugopodium, e-autopodium of fingers, f-heart prominence, g-distal limb zeugopodium, h-distal limb autopodium.

C-E 37 days old: a-developing external ear, b-developing fingers of proximal autopodium, c-developing toes of the distal autopodium.

D-E 42 days old: a-developing pinna, b-stylopodium, celbow flexure, d-zeugopodium, e-autopodium with developing fingers, f-autopodium with developing toes, g-physiologic umbilical hernia. (Klika D. Embryologie. Praha: Avicenum, 1987:384. - 5).
Annex 7: Development of the face.

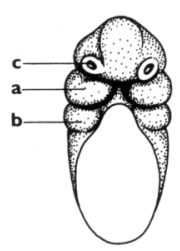

A

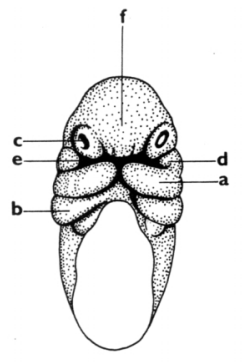

B

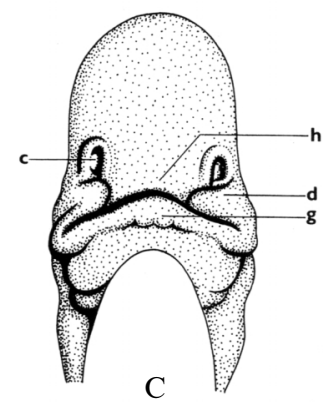

C

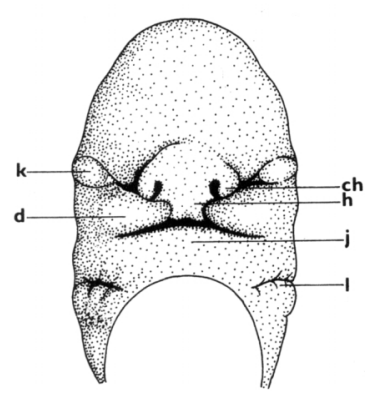

$\mathrm{D}$

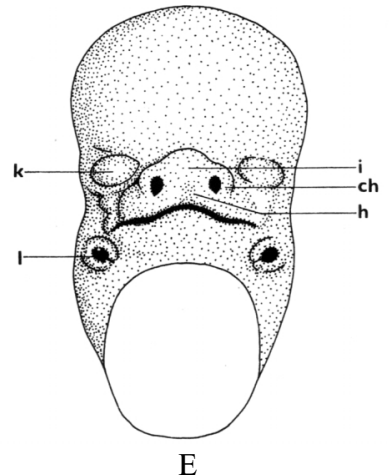

$\mathrm{E}$
A-E long about $6 \mathrm{~mm}$, B-E long about $7 \mathrm{~mm}, \mathrm{C}-\mathrm{E}$ long about $10 \mathrm{~mm}$, D-E long about $15 \mathrm{~mm}$, E-E long about 18 $\mathrm{mm}$.

a-first pharyngeal arch, b-second pharyngeal arch, c-olfactory pit, d-maxillar processus, e-stomodaeum, f-frontal lobe, g-mandibular primordium, h-medial nasal processus, ch-lateral nasal processus, i-triangular area, j-mandibula, klens placode, 1-primordium of the pinna. (Klika D. Embryologie. Praha: Avicenum, 1987:384. - 5).

Annex 8: Scheme of auricle development.

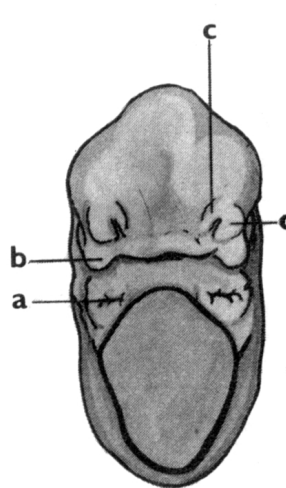

A

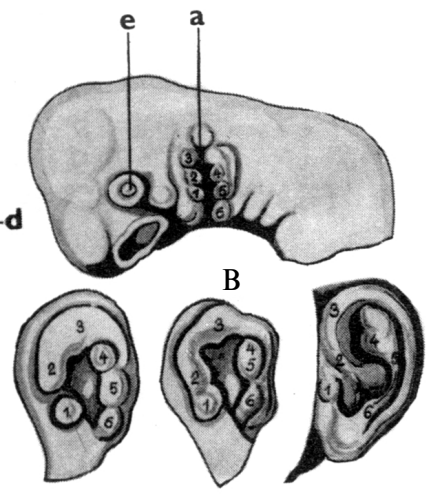

$\mathrm{C}$
$\mathrm{D}$
E
A-E of about $10 \mathrm{~mm}$ length, B-E of about $15 \mathrm{~mm}$ length, C-E of about $20 \mathrm{~mm}$ length, D-F 4 months old, E newborn. a-primordium of the pinne, b-maxillar, processus, c-medial nasal processus, d-lateral nasal processus, e-eye. (Klika D. Embryologie. Praha: Avicenum, 1987:384. - 5). 
Annex 9: Development of the limb.

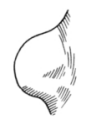

A

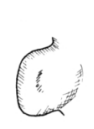

A

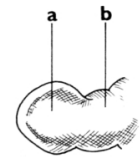

B

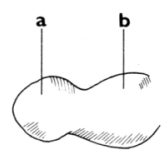

B

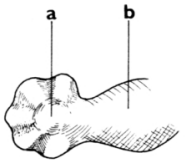

$\mathrm{C}$

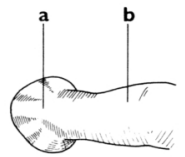

$\mathrm{C}$

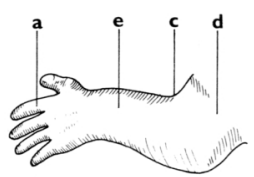

D

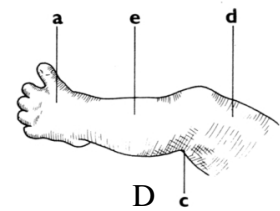

A-E about $7 \mathrm{~mm}$ long, B-E about $8 \mathrm{~mm}$ long, C-E about $15 \mathrm{~mm}$ long, D-E about $25 \mathrm{~mm}$ long. Upper line upper limb, lower line lower limb. a-autopodium, b-zeugopodium, c-flexure of the elbown or knee, d-stalopodium, e-zeugopodium. (Klika D. Embryologie. Praha: Avicenum, 1987:384. - 5). 